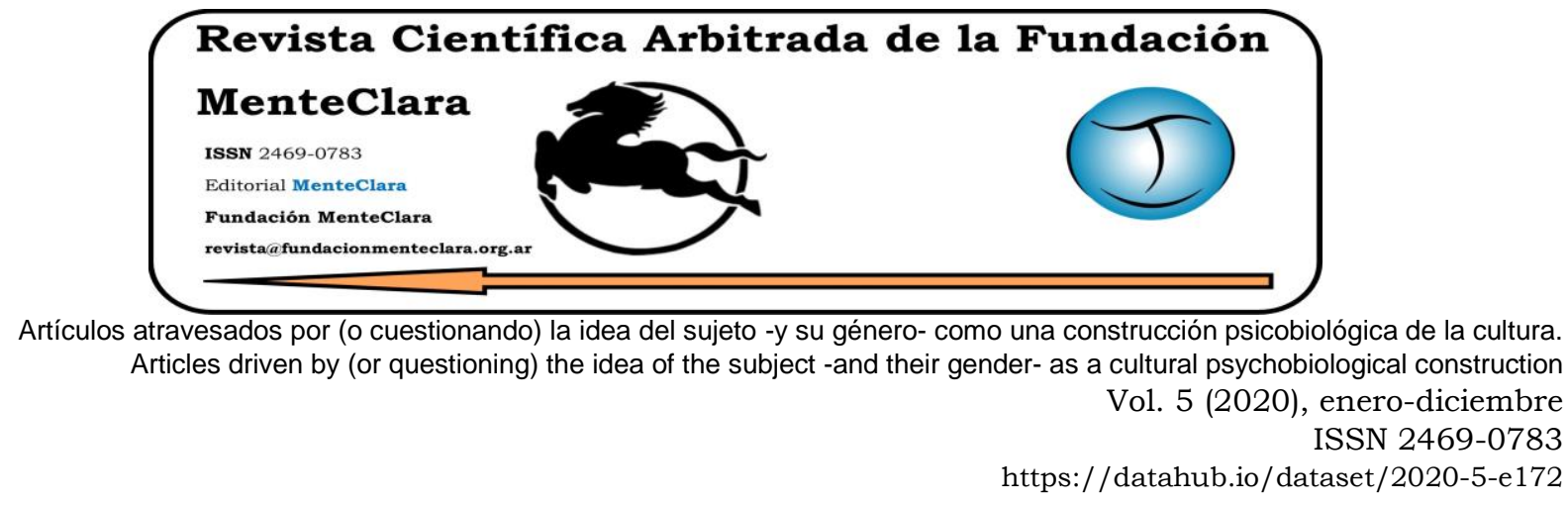

\title{
ONTOLOGICAL EXPERIENCE AND THE ONTIC ONTOLOGICAL HUMAN BEING
}

\section{LA EXPERIENCIA ONTOLÓGICA Y EL SER HUMANO ÓNTICO ONTOLÓGICO}

Rudolph Bauer rbauer@rsbauer.net

Center for Consciousness Studies and Washington Center for Phenomenological and Existential Psychotherapy Studies. United States of America

Cómo citar este artículo / Citation: Bauer R. (2020). "Ontological Experience and the Ontic Ontological Human Being". Revista Científica Arbitrada de la Fundación MenteClara, Vol. 5 (172). DOI: https://doi.org/10.32351/rca.v5.172

Copyright: () 2020 RCAFMC. Este artículo de acceso abierto es distribuido bajo los términos de la licencia Creative Commons Attribution 4.0 International License (CC BY 4.0). Recibido: 05/09/2020. Aceptado: 07/09/2020 Publicación online: 08/09/2020

Conflicto de intereses: None to declare.

\begin{abstract}
This article examines the concepts of Amrita and develops the Khechari Mudra one by integrating such concepts of Tibetan Tantric Buddhism and Hindu Tantrism with the developments of existential phenomenology. It goes from the phenomenology of the mind to the phenomenology of Being in the works of Heidegger, Eugene Fink, Maurice Merleau Ponty, and other phenomenologists.
\end{abstract}

\section{Resumen}

Este artículo expone el concepto de Amrita y desarrolla el Khechari Mudra al tiempo que integra estos conceptos del budismo tántrico tibetano y del tantrismo hindú con los desarrollos de la fenomenología existencial. Hace un recorrido de la fenomenología de la mente a la fenomenología del Ser en los trabajos de Heidegger, Eugene Fink, Maurice Merleau Ponty y otros fenomenólogos. 
Keywords: tantra; Khechari Mudra; Amrita; field of Being; awareness; phenomenology; da sein

Palabras Claves: tantra; Khechari Mudra; Amrita; campo del ser; consciencia; fenomenologia; da sein 


\section{Introduction}

Eugene Fink was the phenomenologist most closely associated with Husserl's later phenomenological work. Eugene Fink's own work was greatly influenced by Martin Heidegger's luminous understanding about our direct perception of Being. Heidegger described our human awareness as a direct opening to Being, and as directly knowing Being.

Heidegger also elaborated the important difference between metaphysics and ontology. Metaphysics was our mind's mental and conceptual elaboration about the nature of Being. Metaphysics is simply our mind's ideation about Being. Metaphysics does not reflect our direct experience of knowing Being. Ontology is the direct knowing of Being and our direct experiencing of Being. Metaphysics is the conceptual knowing of our mind about Being. Ontology is the direct experiential non conceptual knowing of Being by our awareness. Our phenomenological articulation of our experience of Being reflects our direct experience, and direct non conceptual experience of Being. Our experience of Being is often un-thought but known.

In the light of Fink's experience of Heidegger's elaboration of our ontological direct experience of Being, Eugene Fink wrote a paper called the "Material of Ontological Experience". Fink's paper reflects the shift in continental philosophy from the phenomenological focus on our psychological experience of phenomena to the phenomenological focus on our ontological experience of Being and the Being of phenomena (Fink, 1995).

There is the ontological difference between our psychological knowing of phenomena and our direct non conceptual knowing of Being. This is the difference between the cognitive knowing of our mind knowing phenomenological forms, and the direct non conceptual experience of our 
awareness knowing Being. This is the foundational ontological distinction between our human two ways of knowing. There is the phenomenology of mind which is our mind's dualistic knowing of the phenomena of forms, and there is the phenomenology of our awareness which is our direct non conceptual non dualistic knowing the phenomena of Being and the Being of phenomena. We can consider the knowing of our mind is ontic and the knowing of our awareness is ontological. We can of course, by bringing our mind into union with our awareness field, experience an Ontic Ontological experience of our world of Being. We can experience the Being of phenomena! We can also experience the phenomena of Being. We are Ontic-Ontological beings (Love, 2018).

\section{Maurice Merleau Ponty}

There was a similar dramatic unfolding of our two ways of knowing within the work of Maurice Merleau Ponty. Initially Merleau Ponty's focus was the phenomenological study of the perception of the mind. His focus was the mind's phenomenological experience of phenomena and phenomenological form. His great text the "Phenomenology of Perception" reflected his study of the mind's perceptual capacities. Then Merleau Ponty began to study our perception of "field" phenomena and the various perceptual fields of knowing. His phenomenological study of "fields" helped him experience and understand Being as a field. He initially studied Gestalt psychology as a way of studying field phenomena. He eventually focused his study on the ontological field of Being. His last book was a masterful phenomenological study of the field of Being and Being's self- manifestation of beings. This masterful yet unfinished work was the Visible and the Invisible. His text the "Visible and Invisible" was unfinished because of his early death at 53 years old. This text was a text illuminating the ontic ontological experience within the Ontic Ontological 
Human Being. Ontic is the experience of the visible phenomena and Ontological is the experience of the invisible Being of the Phenomena (Wells, 2014).

\section{From the Phenomenology of Mind to the Phenomenology of Being}

In the work of Heidegger, Eugene Fink, Maurice Merleau Ponty and other phenomenologists during this period of time, there was a shift from the phenomenological study of our psychology of mind to the phenomenological study of our innate awareness of Being. This was the natural philosophical unfolding from our dualistic knowing of mind knowing phenomena to the non- dualistic knowing of our awareness knowing Being. Our mind knows the dualistic forms of phenomena and our awareness knows of the non- dualistic Being of phenomena (Capobianco, 2014).

Our awareness directly knows the non -dualistic phenomena of Being. Our mind knows dualistically, and our awareness knows non dualistically. Our mind knows difference and our awareness knows oneness. Our mind knows conceptually and our awareness knows non conceptually.

When we integrate our mind within our awareness field, we can know the duality of beings within the non- duality of Being and we can know the non- duality of Being within the duality of beings. This existential understanding is the essence of the play of the phenomenology of selfliberation. 


\section{From Transcendental Phenomenology to the Existential Phenomenology of Immanence}

During this period of the phenomenological study of Husserl, Fink, Heidegger, Merleau Ponty, Paul Ricœur and many others, there was the unfolding evolution within phenomenological philosophy from a Transcendental Phenomenology to the Existential Phenomenology of Immanence. This transformation within the phenomenological movement was from the early formulations of Transcendental Phenomenology of Husserl to the later formulations of Merleau Ponty's Phenomenology of Immanence (Brunzina, 2004). The early Transcendental Phenomenology focused on how our mind constituted our experience of phenomena from within the Transcendental View, and the later existential phenomenology focused on the unfolding of our direct non conceptual experience of Being of phenomena and our personal experiential embodiment of Being.

\section{Self- Liberation within Transcendental Phenomenology}

Within this transformation within the philosophical field of phenomenology from Transcendental Phenomenology to the Phenomenology of Immanence, there arose a corresponding existential self - illumination of our embodied experience of self -liberation. The Transcendental approach to self- liberation reflects our human capacity for detachment and dissociation in our becoming the transcendental witness or the transcendental knower of phenomenological experience. Husserl often referenced this transcendental knowing as the Transcendental Ego. The Transcendental approach required an intense detachment and dissociation from our phenomenological experience of sense of self, from our of sense of body and from our sense of mind and even from our sense of our world. This process of mental detachment and 
mental dissociation from phenomena and phenomenological experience is hidden within the dissociative intellectualization of the language of reflection, such as the splitting of reflection, the objectification of reflection, the suspension of mind as epoche, and other subtle forms of dissociative mental operations (Daws, 2016).

This detachment brought forth the transcendental ego or transcendental subjectivity which is a powerful form of witness consciousness. This transcendental witness consciousness transcended our human phenomenological embodied experience and became the transcendental knowing of pure consciousness. This knowing of pure consciousness was the knowing of pure consciousness beyond our actual embodied experience of Being. Husserl would often say "what is the wonder of all wonders Pure Consciousness and the doorway is our own subjectivity." In its most subtle form Transcendental Knowing is knowing without a knower! This knowingness without a knower is profoundly dissociative in essence.

\section{Transcendental Knowingness As Self Liberation}

In this transcendental process the transcendental witness or transcendental knowing would go beyond our experience of mind and would go beyond our experience of phenomena, and would go beyond our experience of embodiment, and go beyond our experience of the world.

The transcendental state is beyond our personal experience of embodied self. The transcendental ego or transcendental subjectivity or transcendental witness is a dissociative and detached state of pure knowing, pure consciousness of pure. Transcendental subjectivity is not our personal subjectivity. This phenomenological transcendental process is not radically different, then the many earlier religious historical 
expressions of transcendental dissociative experience. There are many unfolding phases of transcendental philosophy within Buddhism and within Hinduism that are similar in essence, and similar in praxis to Husserl's transcendental phenomenology. Descartes with his foundation method of doubt would also bring forth a form of Transcendental Experience (Fink, 1995).

\section{Self -Liberation within the Direct Knowing of Ontic-Ontological}

\section{Being}

The unfolding of our contemporary phenomenological experience of self- liberation reflects our existential phenomenological understanding that our personal awareness directly and experientially knows Being within our own embodiment of Being. Our personal experience of awareness is the manifestation of primordial Being as our personal being. The knowing of Being is the knowingness of awareness. Our awareness is the knowing of Being knowing Being. Through our Being's knowingness of awareness, our own Being knows Being. Self -Liberation is this close and this immediate. This is the path of Immanence.

Our contemporary phenomenological experience of self- liberation becomes our direct experience of the manifestation of Being as the Being of the phenomenological world, and Being as the self- manifestation of our personal awareness, and as our personal Being-ness of Being itself. The experience of our own singular personal embodied Being as Pure Being is the process of self- liberation. This is the path of Immanence.

Experiencing the phenomenological beings of the world as Pure Being is also the process of self- liberation. And by experiencing the Being of all phenomena as Pure Being is self- liberation. And by our experiencing the Being of the world, and the Being of the universe as Pure Being itself is 
self -liberation. By our experiencing the Purity of Being of all beings including our own Being is self -liberation. This is the path of Immanence.

Through our embodiment of our awareness as Being we experience self -liberation within our own personal Being as Pure Being. Moreover, our experience of all phenomena as forms of Being and our experience of our phenomenological Self as Being is a vital source of self- liberation. This contemporary form of self -liberation is naturalistic and this path of self -liberation takes place within in our life of Being within the events of Being just as we are. Our self- liberation is through the events and circumstances of our life. The events and circumstances of our life are the self-manifestations of Pure Being. This is the path of Immanence.

To directly experience our purity of Being is self-liberation. To experience the Purity of Being of all beings is the unfolding experience of self- liberation of Equality Consciousness and Equal Vision. Selfliberation within the Immanence of Being is Equality Consciousness and Equal Vision.

\section{Being Beyond Phenomena}

Self- liberation through and within the immanence of Being is not the self-liberation of transcendental experience. The self -realization through transcendental experience is at best an Unbound Knowingness without "Who-ness". The transcendental experience is non- relational and ontologically solipsistic. There is no one there. There is no who-ness there. The transcendental Ego is non- personal consciousness. This experience of non- personal consciousness brings forth the existential human problem of the metabolizing of experience and the human problem of the actuality of subjectivity as self- determination. In transcendental knowing metabolization of phenomena is not truly 
possible. In transcendental knowing there is no personal subjectivity and there is the consequent absence of self -agency (Bauer, 2019).

Transcendental Knowing is Ontological Knowing beyond Ontic-ness. Transcendental Liberation is Beyond Our Ontic Being. Transcendental Knowing is Transcendental Ontology without Ontic elaboration and Ontic personification. There is a foundational and fundamental dissociation between the knowing embodied personal experience of phenomena and the transcendental knowingness beyond a knower and beyond personal who-ness. The transcendental knowingness is beyond phenomena.

\section{Ontic Ontological Experience within the Ordinary Life World}

Fink work's consistently articulated that human beings are the mysterious intertwining of Psychology and Ontology. Psychology is Ontic. Human beings are the intertwining of the Ontic dimension and the Ontological dimension. For Fink our human mind is profoundly psychological and our human awareness is profoundly ontological. We are psychosomatic within our Ontic- Ontological embodiment. Our world is the ontic ontological field of Being and we ourselves are onticontological fields of Being as beings who experience and know Being within the being of our life, and within the phenomena of the Being of our life world. Human awareness directly knows Being. Human beings are both a psychological being and an ontological being.

Fink and Merleau Ponty under the luminous influence of Heideggerian phenomenology and Husserl's later unpublished studies of ontological inter-subjectivity understood and directly experienced the phenomenological dimensions within our experiencing of the phenomena of Being and the Being of phenomena. There is the natural field of the ordinary life world to use Husserl's language wherein we experience our 
ordinary life world as the realm of Being as phenomena and our experiencing the Being of the life world within phenomena.

This understanding that our ordinary life world is the realm of Being as phenomena reminds us of the great prayer of Dzogchen. May I experience all phenomena as the Dharmakaya. Dharmakaya is Pure Being self- manifesting as the Being of phenomena, including our own phenomena of our own person (Rinpoche, 2005).

\section{Human Being as Ontic-Ontological Experience: Zollikon Seminar}

Heidegger's collaborated with the psychiatrist Medard Boss in an ongoing clinical seminar that focused on the ontic ontological understanding of the human being. The seminar illuminated the experience of the ontic ontological understanding of the human person. Medard Boss had studied with Freud and later with Jung. Heidegger had personally experienced an existential collapse and disintegration and had worked successfully with Medard Boss in existential psychotherapy.

Medard Boss and Martin Heidegger together lead the seminar. This Zollikon Seminar continued from 1959 through 1969 during the summer of each year. Many existential psychoanalysts and existential psychotherapists were introduced to the ontic ontological view. A school of Existential Psychotherapy emerged during this seminar called Dasein analysis. $D a$ sein analysis explores experientially ontic-ontological existence. The seminar focused on the interface between our ontic dimension of psychological mindedness and the ontological dimension of our depth of Being. Human beings have this foundational openness to Being and this spacious knowing openness is in interface with our mind of thinking, feeling, sensation, memory, reasoning and imagination. 
The seminar focused on the various dimensions of Human Being-ness. There was at times a focus on the dimension of our ontic ontological experience of the ordinary life world. There was at times a focus on the experiential manifestation of the elemental archetypal realm of Being. And there was a focus on our direct experience of the ground of Being which is known as potential space.

Ontic Ontological Archetypal Experience is the archetypal dimension of Being and can be experienced both in Existential Phenomenology as well as in the Dzogchen. Many philosophies and theologies have explore this elemental archetypal ontic ontological dimension of our human experience. This is the luminous energetic dimension of ontological archetypal manifestation of primordial energies and symbolic structures of experience.

\section{Self -Liberation within the Elemental Archetypal Dimension Of}

\section{Being}

Carl Jung also discovered that beyond our psychology of mind there was this dimension of consciousness that was archetypal, energetic and elemental in nature. Jung discovered the archetypal dimension of human experience with psychotherapy. Jung discovered this dimension within his patient's imagery and within their personal in- depth psychological experience. Jung also discovered this dimension of human experience within the ancient gnostic and hermeneutic text as well as mythic and theological text of various religious traditions including the Christian traditions.

Jung's was preoccupied with his question about the nature of this elemental archetypal phenomena. His question was this: Is this psychology or is this ontology? Is this ontic or ontological? Is this human 
archetypal drama ontic or ontological? Is this drama of the mind alone or is this the drama of ontological Being in its manifestations? Is this phenomena of the archetypal dimension, the collective memory of past psychological experience or is this archetypal dimension the experience of a more primal dimension of Being that actually manifests the ordinary reality of our life world as well as our psyche?

In his Red Book Jung seems to come to the conclusion that this elemental archetypal dimension is both a dimension of Being and personal psychology. This is what Dzogchen calls the Sambhogakaya dimension of Being. This is what Lacan would call the Symbolic realm of Being. These are ontological dimensions of Being that greatly infuse our personal and collective ontological existence.

There are other psychology and spiritual traditions that consider the archetypal to be only ontic and simply psychological. For these traditions, archetypal experience is simply a form of psychological dreaming. For Existential Phenomenology and for Dzogchen the archetypal dimension is the intertwining of the ontological ontic dimensions of our human existence (Lingpa, 2015).

Within our phenomenological ontology, there is the elemental becoming of beings. This is described in the tradition of phenomenological archetypal psychology by Richard Tarnas, James Hillman and other contemporary archetypal existential psychotherapist. This is the primal primordial dimension of self -manifestation of Being becoming our being. Heidegger focused on this elemental dimension of Being in his work on the Pre-Socratics and Heraclitus. This period took place around the year of 1944 wherein the elemental archetypal theme emerged including the Logos (Heidegger, 1988). 


\section{Self- Liberation Through Our Experience of Pure Being, Pure Potential Space}

There is the foundational dimension of pure creative Being that is opened in Phenomenology and in Dzogchen. This dimension is Pure Being as creative source. This is pure Being as pure manifesting. Heidegger calls this dimension Phusis. This is the profound dimension of our experiencing of Being as pure potential space, pure potential openness infinite in its horizons. This is our experience of pure Being which is not a being, but Being self- manifesting as infinite numbers of beings. This is the dimension of Being as source that is both un-manifest and manifest. This is the dimension of indeterminacy of pure potential space. Pure indeterminateness! This is Pure Being of unbound spacious openness as indeterminable freedom of manifestation. This is the place of the manifest and the un-manifest. This is the openness of Being of pure manifesting.

This dimension of open manifestation is wonderfully elaborated by Donald Winnicott, Rollo May and Michael Eigen and many other existential psychoanalysts (Winnicott, 2005). This is also described in the Dzogchen tradition as the Dharmakaya or the Ground of Being. Longchenpa was a $14^{\text {th }}$ century Dzogchen teacher who wrote directly and experientially about this foundational dimension of human existence. The process of personal manifestation is also described by the $6^{\text {th }}$ century CE Buddhist monk named Bodhidharma as follows "Beyond words and letters there is a transmission, this transmission does not belong to any tradition. It is the very nature of human awareness" (Longchen, 2001). 


\section{Ontic Ontological Experience of the Self Manifestation of}

\section{Luminosity: The Body of Light}

As our mind becomes metabolized within the field of the Being of Awareness, the mind becomes more infused by the radiance of the innermost field of luminous awareness. The union between mind and awareness becomes more continuous and complete. The foundational dissociation between mind and awareness is metabolized and dissolved. There is a continuity of experience within our mind awareness field continuum. Often this experience is described as the heart mind continuum. This heart mind continuum is most important and focal understanding in Existential Phenomenology and in Dzogchen.

Beyond the metabolizing of our mind within the field of our luminous Being of awareness, our field of embodied luminous Being becomes unbound openness and the unbound radiance of our field of Being spreads throughout our body and beyond our body. The luminous embodiment of radiant light becomes more and more manifest, and the innermost radiance is felt and the felt sense of luminosity permeates our body and our embodied field of the flesh.

The power of our luminous innermost awareness is pervasive and our direct knowing of Being within our own embodiment becomes more experientially felt as luminous presence, and the felt sense of the luminous vibration and luminous pulsation is easily experienced and felt throughout our body. The field of luminous embodied Being is experienced and felt as our own embodiment of radiant light. We become the felt sense of the radiance of luminous presence.

As our field of embodied Being becomes pure openness the luminous radiance shines forth within us and beyond us. The luminous radiant light and luminous energy opens the most subtle dimensions of our 
embodied light and our felt sense of light begins to manifest through and within our embodiment as luminous Being-ness. The radiant light configures our innermost experience of our embodied luminous flesh.

\section{Amrita and The Khechari Mudra}

Our embodied field of radiance begins to arise and expand through our embodied field of Being. As the field of embodied light arises and manifests through our different energy centers, a column of emerging light is experienced. The light manifests as subtle liquid like luminous phenomena that manifests in our field of awareness embodied throughout our body. This nectarine liquidity is called in the Dzogchen tradition Amrita. There is the myth of Amrita being the water of life. This water of life is concealed in the depth of the ocean of Being, and this Amrita is a food of the divinities of Being. This luminous liquidity of Being arises from the depths of our embodied Being and permeates the palette of our mouth and flows throughout our body (Giusti, 2018).

This Nectarous like nectar flows through our embodiment of awareness, our embodiment of the field of Being. This Nectarous viscous water of life dissolves introjected energies of negation and this liquidity of Being supports us in abiding in the field of luminosity. This ambrosia liquid like experience of the felt field of Being pervades our luminous embodied awareness. This liquid like Nectarine experience pervades our field of awareness and pervades our sense of embodiment. This Nectarine experience is blissful. This blissfulness dissolves suffering.

The Dzogchen tradition in its esoteric archetypal text describes that this liquidity of Being arises from the invisible celestial land of Khechari. Khechari is a heavenly realm, the Sambogakaya realm, the Archetypal 
realm, the Realm of the Dakini and the realm of Khechari Mudra ${ }^{1}$. The Khechari mudra is the realm of our inner palette. The inner palette opens the door to Nectarine states, the womb of the shakti. The celestial realm is not a transcendental realm. This celestial realm is within our embodiment of Being. This celestial realm is within the palette of our mouth. The palette opens the subtle realm of our Being and we experience the flow of Amrita. This is a sublime expression of immanence and the non- dual oneness of beatific-ness within the immanence of our Pure Being.

The implications of the manifestation of Khechari Mudra are many. The manifestation of the Khechari Mudra is the manifestation of protection from harmful human energies. The manifestation of the Khechari Mudra is a symbolic indication that the person is experiencing self- liberation in this life. And the manifestation of Khechari Mudra is the manifestation of the experience of deathless awareness. The manifestation of the experience of deathless awareness indicates the dissolving of profound annihilation and death anxiety. The Khechari Mudra symbolizes self liberation in the unfolding as the liquidity of Being. The fluidity of Being is the ongoing and continuous experience of the lightness of our Being.

The Khechari Mudra is expressed in many different ancient traditions throughout the centuries. The Khechari Mudra is experienced in Dzogchen Tradition, in the Buddhist Vajrayana tradition and within the Hindu Vedantic traditions. The Khechari Mudra was also described in the

\footnotetext{
${ }^{1}$ Khecarī Mudrā (Sanskrit, खेचरी मुद्रा ) is a hatha yoga practice carried out by curling the tip of the tongue back into the mouth until it reaches above the soft palate and into the nasal cavity. Bhattacharyya defines Khecari Mudrā as the "Yogic posture which bestows spiritual attainment and enables one to overcome disease and death." He explains that Kha denotes brahman, and that power which moves (cara) as the kinetic energy of brahman is known as Khecari"(Bhattacharyya, 1999). Khecarī Mudrā is the bliss of the vast expanse of spiritual consciousness, also known as divya mudrā or Śivāvasthā (the state of Śivā). Also identifies with a higher sense-with the end state of consciousness, and not just the physical posture used to achieve that end, a state of universal consciousness which is the state of Siva. Abhinavagupta, in his Tantraloka, states that all other mudras derive from khecari mudrā, which he describes as "the stance of moving or flying through the void of the supreme consciousness" (Mukund, 1918).
} 
gnostic and hermetic traditions. It is described by many Christian saints and even early Greek philosophers. Sri Rama Krishna often described this experience of luminous liquidity (Baumer, 2011).

This experience of Nectarine states is not a function of transcendental realization with the grandiose implications of omniscience and omnipotence. There is no implication of the experience of Amrita being a function of Omnipotence or Omniscience or Absolute Knowledge. Self liberation is not the experience of being the One Who Knows Absolutely. This is the patriarchal fantasy, the patriarchal illusion, patriarchal grandiosity (Bauer, 2020).

In the deepest sense and the fullest sense the experience of Amrita reflects the experience of timeless awareness manifesting in time. Amrita reflects the experience of the ontological manifesting and blending within the Ontic dimension of our existence.

\section{Ontic Ontological Experience In Dzogchen and In Phenomenology}

Dzogchen and Phenomenology share the ontic ontological experience and the ontic ontological view of the human Being. Both traditions have their understanding grounded in the phenomenological self -illumination of the unfolding of our experience of Being as our personal direct knowing. Human beings have a direct openness to the experience of luminous Being and the luminous Being of phenomena.

Dzogchen and Phenomenology illuminates the ontic experience of our psychological mind knowing the forms of phenomena. Both traditions of Dzogchen and Phenomenology illuminate the ontological dimension by their emphasis on the power of our awareness which is our direct knowing of Being as Being and our awareness directly knowing the Being of phenomena. Our mind knows the phenomena of form which is Ontic. 
Our awareness knows the Being of Phenomena which is ontological. In our union of mind and awareness we experience ontic ontological existence. This is the path of Immanence. This is the path of selfliberation.

Both Phenomenology and Dzogchen directly understand the nature of Being as spaciousness, the nature of Being as creative openness, the nature of Being as the radiance of presence, the nature of Being as vital energy and the nature of Being as the light of radiance. The nature of Being is manifestation. Both Dzogchen and Phenomenology understand that the self-manifestation of Being is an ontological process. Our experience of Being is an ontological process. Our mind's experience of phenomena is Ontic and psychological.

In Dzogchen as in Phenomenology there is the foundational distinction between the two ways of knowing. There is our knowing of mind knowing the form of phenomena and there is the knowing of our awareness directly knowing Being. Our non- conceptual awareness directly knowing Being is ontological knowing. And our mind knowing the form of phenomena is Ontic knowing, and is psychological knowing. And within Dzogchen and within phenomenology there is necessary integration of our mind within our field of awareness. When mind and awareness integrate there is the ontic ontological union and there is simultaneous ontic ontological knowing.

This union of mind within awareness brings forth our capacity to directly know the Being of phenomena and the phenomena of Being simultaneously. This union allows us to experience the non-duality of Being within the duality of beings. This union of our mind within our awareness allows us to experience within the duality of beings the nonduality of Being. Our natural experience of the Being of beings is the ongoing source of self- liberation. 
This is the nature of the Ontic Ontological experience. Ontic reflects our mind knowing of phenomena and the ontological reflects our awareness directly knowing Being. The ontic ontological union allows us to know the Being of phenomena and the phenomena of Being. As the Dakini said to Dudjom Lingpa "You and I are indivisible". "There is a you and there is an I and there is indivisibleness".

Both Dzogchen and Existential Phenomenology emphasize the necessary integration of our mind within our awareness field. Our Awareness is our direct opening to the field of Being that liberates us from being our contained within the form of mind without the luminous base of Being. Our mind and body can be integrated into the base of the ontological presence of radiant Being. Our experiential embodiment of Being illuminates us and liberates us within the radiance of spontaneous presence.

In both Dzogchen and in Existential Phenomenology, there is the experiential unfolding from within our integration of our mind within the field of Being. We can then experience the self -arising of the dramatic experience of our self- liberation through our experiencing our own Being as the luminous field of Being. By embodying Being, by becoming Being, by living within Being self -liberation happens. The Bliss of Being is the Bliss of Freedom. The vital energy of Being expands our luminous spontaneous ontological presence in the world of Being.

Dzogchen tradition names this direct knowing of Being Gnosis or Jnana. In both phenomenology and Dzogchen there is the methodological shift from being in mind alone to our becoming aware of awareness which opens our direct experience of the field of Being. There the shift from being located in mind alone to our integrating our mind within the field of Being and our embodying the field of Being. As our experience of Being 
unfolds within the circumstances and events of our life we experience our self as the field of Being. This is self- liberation (Bauer, 2017).

This union of our mind within awareness allows us to experience the non -duality of Being within the duality of beings and within the duality of phenomena the non- duality of Being. We are able to experience the duality of beings within the non-duality of Being. Within the union of our knowing of mind knowing phenomena dualistically and our awareness knowing Being non - dualistically we can know oneness and difference simultaneously. We can know phenomena and Being simultaneously. As the Dakini said to Dudjom Lingpa "you and I are indivisible". We can live within indivisibleness of Pure Being just as we are.

Our initial movement of self- liberation is to integrate our experience of our mind within the field of our awareness which is actually the field of Being. The power of awareness is our direct knowing of Being and awareness is also the power of the metabolism of experience. This metabolizing of experience is most important in understanding existential self- liberation.

\section{Ontic Ontological Metabolism}

Our metabolism of our ongoing experience of phenomena, assimilates everything into the field of Being. This metabolizing of experience integrates everything into the field of luminous Being and into the presence of Being. This metabolism of our experience of phenomena brings forth the intense refinement of perception to experience Being and to experience within the manifesting of the events of Being our selfliberation within the spaciousness of Being and the radiance of the light of Being. 
The metabolism of phenomena dissolves phenomena and what remains is the light and energy of Being. Phenomena dissolves into the becoming of Being. Phenomena dissolves into the trans-lucidity of Being. Phenomena is metabolized into the radiant field of Being. Phenomena is essentially the light of Being. Phenomena is actually the light of Being, the radiance of Being. Through this process of metabolism, the embodiment of light takes place. Through this process the subtle body of light emerges within us as a luminous embodiment. Phenomena is metabolized and light of Being remains.

After the phase of integration of mind within awareness what unfolds is the deepening of the experience of Being and refining of our perception of Being, and becoming Being. Being is not an ideation or belief. Being is an unfolding experience. Being is the infinity of experience. There is a similar unfolding of understanding within the Dzogchen tradition. Wherein the person is aware of their mind as a form of Being, then the experience of mind becomes the direct experiencing of Being and the experiencing Being as the phenomena of mind. There is the shift from being in mind alone to our mind being experientially infused by the field of Being and our mind becomes luminous Being-ness. Our heart mind connection becomes our Heart of Being.

\section{The Politics of Self Liberation Within Our Ontic Ontological Experience}

From the view of our mind knowing phenomenological form and our awareness directly knowing Being, and the Being of the form, the view of Equality Consciousness and Equal Vision emerges within us as the experience of self - liberation. 
In Hegel's Phenomenology of Spirit Hegel suggest that within our collective psychological experience there is a desire for a Person who Knows Omnisciently and who has Absolute knowledge. This compelling desire is for the Patriarchal Master who has Absolute knowledge. This Patriarchal experience is a collective symbolic function of and within our human mind and within human culture. The Patriarchal omniscient Master who knows absolute knowledge is an actuality within our personal human psychology and collective human psychology. Hegel in his great text "Phenomenology of Spirit" elaborates the compelling power of this symbolic Master of Absolute knowledge who is the One who Knows.

This compelling desire to experience the Patriarchal Master who has Absolute Knowledge brings us into systemic Master Slave relationship. If there is the Master there will be the slave. There is a vast number of social psychological studies about the authoritarian character of the authoritarian followers in religion, in politics and in cultural life. These followers of the one who knows absolutely are deeply dependent beings! These dependent followers fall easily into the dependency of the Master Slave relationship (Bauer, 1976).

The Master Slave relationship reflects our psychological desire for endless dependency on Patriarchal Authority and Authoritarian omniscience. This relentless manifestation of the master slave relationship within us destroys our experience of Equality Consciousness and Equal Vision. When we as a person takes refuge in the Master Slave relationship we can lose our sense of inherent freedom and selfliberation.

We need and desire the Master because of our profound sense of the lack of inner Being-ness within our self as our self. 
When we are located within our mind alone, there can be the collapse of our authentic experience of embodiment of our Being of our innermost sense of self. When we as a person takes refuge within our ontological awareness of Being, we can experience the presence of Being and the spaciousness and energy of the field of Being within ourselves and within others. Through our experiencing of our embodiment of Being we can enter naturally into the experience of Equality Consciousness and Equal Vision. We can enter naturally into the field of Being and live within the field of Being.

Our direct and non- conceptual experience of the presence of our embodied Being can bring forth the experience of Equality Consciousness and Equal Vision within our self and within others. By taking refuge within the field of awareness a person can experience the Presence of Being within themselves and within others. Our experience of the field of Being brings forth the liberating experience of Equality Consciousness of the Purity of Being of all beings. Taking refuge in the ontological dimension of our awareness of Being can liberate us from our compulsive desire for omniscience and absolute knowledge. Omniscience and absolute knowledge is not the direct knowingness of self- liberation. The direct knowing of self -liberation is our awareness directly non conceptually knowing and experiencing Being and the Presence and qualities of being Being.

Our experiential awareness of the Equality of Being and the non duality of Being can deconstruct the hierarchal Master Slave relationship and metabolize our dependency on and within the Master Slave relationship.

Hegel elaborates that this Master Slave experience ultimately brings forth an experience of terror of our fragile dependency on the one who knows absolutely. To free our self from the slavery of total dependency on 
the one who knows absolutely, we must be willing to suffer the loss of our total dependency. This loss can feel like death. This loss can feel like annihilation. Without our innermost sense of Being-ness as our inner self and without our inner sense of our innate ontological ground or base of Being, and without our ontological sense of self as our field of Being, this freeing of our self of our dependency on the Master who knows absolute knowledge is terrifyingly difficult.

By taking refuge within our own awareness which is our opening to the field of Being, the non- duality of Being is directly experienced and known. Equality consciousness is a function of our direct experience of Being within our own self knowing of our own Being and the Being of the other. Experiencing the direct knowing of Being and the innermost presence of Being liberates our person from the domination of Patriarchal Field.

\section{Ontological Lack and The Terror Dependency}

The Patriarchal Master who knows Absolute knowledge is both a substitute and compensation for our own existential absence of our ontological sense of self and for our own ontological lack of our sense of our embodied Field of luminous Being. This Ontic emptiness is not simply psychological which it is, but this profound lack is the absence of and the void of our innermost sense of our ontological field of Being embodied. This absence of Being is simultaneously our absence of our own innermost sense of self and our innermost sense of ongoing continuity of luminous Being. To be empty of Being and to be empty of self is agony and is terrifying.

When we are empty of Being and when we are Being-less we substitute and compensate for this terrible absence. This terrible absence of Being, 
this Being-less-ness, is compensated for by this omnipotent imaginal fantasy of the Master who has absolute knowledge. This imaginary substitution of the One who has Absolute knowledge is a compensation for own lack of our innermost sense of our embodiment of Being. Within this abyss of Being-less-ness, we enter into an imaginal relationship with our would be Master who is the One who has absolute knowledge and who is omniscient. This relationship may both be actual and imaginary at the same time.

\section{Self -Realization Or Self Liberation}

Another and even more subtle substitution and compensation is our own imaginal desire for "self -realization". Imaginal self- realization is the fictional desire for the experience of becoming omniscient and omnipotent and having absolute knowledge like the Buddha or Shiva. We often equate self-realization as knowing absolute knowledge and being omniscient and being omnipotent. This is of course is fiction. Omnipotence and omniscience does not free us from the absence of the ongoing continuity of Being. The desire for Realization becomes a fictional state of omnipotence and omniscience as is the fiction of having absolute knowledge.

In this context of self-liberation, realization is perceived as grandiose state of being which does not exist. The Buddha was characterzed as omniscience by mythic hear say. Within our imaginal level of mind, this imaginal grandiose state compensates and substitutes for our terrible emptiness of Being and absence of self and absence of meaningful experience.

In actuality Self- Liberation is the natural unfolding of Equality Consciousness and Equal Vision life after life and death after death. 
Omniscience and omnipotence are totally illusionary. Omniscience and omnipotence are simply grandiosity. Grandiosity is always a poor substitute for the absence of innermost sense of Being. Grandiosity is a compensation for absence of our innermost self and our absence of an innermost sense of ongoing continuity of Being. Grandiosity is illusionary, fictional and imaginal. Grandiosity forecloses the Bliss of the ordinary.

\section{Una Voce}

The oneness of Being, is the sameness of all Being. Una Voce as Dun Scotus described this oneness of Being, overcomes the analogy view of Being which is a distorted view of Being as being asymmetrical and innately hierarchal. This tragic misconception of the inequality of Being is the source of above and below, better and best, and continuously destroys Equality Consciousness and Equal Vision. This view of the analogy of Being destroys the naturalness and immediacy of selfliberation.

The historical medieval catholic scholastic Thomistic tradition within Christianity has contributed to the misunderstanding of the nature of Being as analogy. Scholastic Thomistic philosophy presented the view of the Analogy of Being with the understanding that not all beings are of the same Being. Not all Being is equal. There are shades of Being. Some beings are better Being then other being's Being. This is a fundamental ontological distortion within our world of One Being. All Being is Pure Being.

One day St. Thomas Aquinas the great philosopher and theologian of the analogy of Being had the direct experience of his misunderstanding of the nature of Being as analogy through a direct luminous vision of the 
Divine Mother Mary. He was stunned and he realized his writing was just straw and so he never wrote again. There is only one Being.

\section{Beyond Domination}

Going beyond the domination of the One Who Knows Absolutely, frees us from the Symbolic Archetypal Power of the "would be" omniscient, omnipotent One who has Absolute knowledge. We free ourselves from the Master Slave relationship that Hegel so brilliantly elaborates in The Phenomenology of Spirit. Self-Liberation is the unfolding of our profound experience of Equality Consciousness and Equal Vision which is the experience of the Equality of the field of Being within all beings as all beings.

This ontic ontological view of immanence is not the transcendental experience where there is "knowingness" without who-ness. Liberation arises naturally for those who live within the field of Embodied Being of awareness. To live in and to experience directly the field of Being is to live within Equality Consciousness and Equal Vision. Self-Liberation is Equal Vision. Self- liberation is Equality Consciousness. Liberation is living within the field of Being as our own who-ness life after life and death after death.

I will end with a comment from Dudjom Rinpoche the great contemporary Dzogchen teacher. "Although hundreds or thousands of explanations are given, there is only one thing to be understood-Know the one thing that liberates everything-Awareness itself, your own nature." 


\section{References}

Bauer, R (1976). A Gestalt Approach to Internal Objects, Psychotherapy, Research and Practice. Vol. 13

Bauer, R (2017). The Natural Hiddenness of the Luminous Experience of Being within Human Beings. Transmission: The Journal Of The Awareness Field. Vol 8

Bauer, R. (2019). The Absence of Self: An Existential Phenomenological View of the Anatman Experience. The Journal of Philosophical Investigations, Vol.13 (28)

Bauer, R. (2020). Human Egalitarianism and the Patriarchal Illusion: A Phenomenological View. Revista Científica Arbitrada de la Fundación MenteClara, Vol.5 (122) doi: https://doi.org/10.32351/rca.v5.122.

Baumer, B. (2011). Abhinavagupta's Hermeneutics of the Absolute Anuttaraprakriya. Delhi: DK Printworld.

Bhattacharyya, N. N. (1999). History of the Tantric Religion (Second Revised ed.), New Delhi: Manohar, ISBN 81-7304-025-7

Brunzina, R. (2004). Edmund Husserl \& Eugen Fink: Beginnings and Ends in Phenomenology 1928-1938. Yale University Press, New Haven and London.

Capobianco, R. (2014). Heidegger's way of being. University of Toronto Press.

Daws, L. (2016). On the Origin of the Self, The Collected Papers of Henry Elkin.

Fink, E. (1995). Sixth Cartesian meditation: The idea of a transcendental theory of method. Indiana University Press.

Giusti, I. (2018). The Transformation of the Body Through Spiritual Somatic Liquid-like Phenomena in the Path to Enlightenment, or Union with God, in Eight Mystical Paths: A Comparative Analysis. California Institute of Integral Studies.

Heidegger, M. (1988). Heraclitus, Bloomsberry Academic, London. Translated by Julia Goesser Assaiante.

Lingpa, Dudjom (2015). The Vadra Essence. Wisdom Publications. Translated by Allan Wallace.

Longchen, Rabjam (2001). Treasure Trove of Scriptural Transmission, Padam Publishing. Translated by Richard Barron. 
Love, J. (2018). The Black Circle: A Life of Alexandre Kojève. Columbia University Press.

Mukund Rām Shāstrī, ed. (1918). The Tantrāloka of Abhinava Gupta. Vol. 1. Commentary by Rājānaka Jayaratha. Allahabad: Indian Press.

Rinpoche, D. (2005). Wisdom Nectar. Trans. and Intro. Ron Garry. Ithaca, NY: Snow Lion Publications.

Wells, A. (2014). Ontological experience. Journal of Scriptural Reasoning, 13(1), 1-11.

Winnicott, D. W. (2005). Playing and reality (1971). London and New York: Routledge. 